Available online at GSC Online Press Directory

GSC Biological and Pharmaceutical Sciences

e-ISSN: 2581-3250, CODEN (USA): GBPSC2

Journal homepage: https://www.gsconlinepress.com/journals/gscbps

(RESEARCH ARTICLE)

\title{
Influence of different processing methods on proximate and anti- nutritional value of tigernuts (Cyperus esculentus L.)
}

\author{
Umaru Hauwa Aduwamai ${ }^{2}$, Umaru Isaac John ${ }^{1}$, Aminu A ${ }^{2}$ and Umaru Kerenhappuch Isaac ${ }^{3}$ \\ ${ }^{1}$ Department of Biochemistry Federal university wukari Taraba State, Nigeria. \\ ${ }^{2}$ Department of Biochemistry Moddibo Adama Federal University of Technology Yola, Nigeria. \\ ${ }^{3}$ Department of Biochemistry University of Maiduguri, Borno State Nigeria.
}

Publication history: Received on 21 May 2018; revised on 07 June 2018; accepted on 12 June 2018

Article DOI: https://doi.org/10.30574/gscbps.2018.3.3.0039

\begin{abstract}
Tigernut (Cyperus esculentus) is an underutilized crop of the family Cyperaceae which produces rhizomes from the base and tubers that are somewhat spherical. An investigation into the effect of different processing methods on the proximate and nutritional contents of tiger nut (Cyperus esculentus) was ascertained. The objectives is to assess the nutrient composition (carbohydrate protein and fat content) of tiger nut and to determine the effect of different processing method on the nutritional quality of the nut since its medicinal significance function helps to promote normal muscles and nerve functions to keep the heart beat steady, support immune functions strengthen bones and keep blood pressure at healthy levels. Moisture content was highest in soaked sample $(10.69 \%)$ while the ash content was found to be low in fried sample (5.47\%). Protein high in soaked sample (14.27\%) compared with fried sample (13.73\%). Carbohydrate was highest (64.13\%) in fried sample than in soaked sample, 958.90\%) saponin was absent in all the sample, tannin completely absent in fried sample, oxalate was absent in soaked sample but high in fried sample (1.47\%) when compared with normal sample which was (1.07\%). Soaking could be considered as the best processing method for tigernut since it reduces antinutrient content and still retains the nutrient value of the nut. Result from this study suggest that tigernut could be used as diabetic and weaning food because of its nutrient composition.
\end{abstract}

Keywords: Tiger nut; Diabetic; fried; Soaking; Cyperus esculentus

\section{Introduction}

Tigernut (Cyperus esculentus L.) is an underutilized crop which belongs to the division Magnoliophyte, class liliopsida, order - cyperales and family-Cyperaceae (family) and was found to be a cosmopolitan perennial crop of the same genus as the papyrus plant. Common names of the plant are earth almond as well as yellow nut grass [1-2]. The production and distribution of tiger nuts in Nigeria is seasonal this fluctuate with season of abundance and scarcity which brings the inability to explore the nutrition content and its medicinal value. It is an edible perennial grass-like C4 plant of the sedge family [3]. Tigernut is tuber usable grass and called chufa, nut grass, yellow nut sedge, earth almond, edible galingale and ground almond [4-5]. It is widely used for human and animal consumption as a nutritious food and feed in Africa, Europe and America [5].

Tigernuts are regarded as digestive tonic having a heating and drying effect on the digestive system, promoting urine production stimulant and used in the treatment of indigestion, sort throat, cough, and Atherosclerosis. The nuts are used as herbs and spices to prevent heart attack and thrombosis and increase blood circulation and said to decrease the risk of colon cancer and in Asia it is said to increase female breast milk [6].

\footnotetext{
${ }^{*}$ Corresponding author

E-mail address: isaac.j62@ yahoo.com
}

Copyright (C) 2018 Author(s) retain the copyright of this article. This article is published under the terms of the Creative Commons Attribution Liscense 4.0. 
Tigernut (Cyperus esculentus) produce rhizoids from the base and tubers that are somehow spherical. They are cultivated throughout the world, especially in the West African countries and Northern part of Nigeria the nuts are found to be a good substitute for cereal grains, it has the characteristics of weaning food [7] as food adjunct for breast feeding. Tiger nuts contain minerals like Chromium, Magnesium, manganese, ferrous iron, Copper, zinc, and vitamin E and vitamin C, Amino acid, and B complex. It is rich in starch mineral and vitamin E and C. Because of this nutritional value Tiger nuts was found to be a good substitute for cereal grains, they are valued for its high nutrition starch content, dietary fiber, carbohydrate and high oil content lauric acid grade [8].

The nut was reported to be rich in sodium, Calcium, potassium, and trace of copper [9]. It also contains magnesium which helps to promote normal muscles and nerve functions to keep the heart beat steady, support immune functions strengthen bones and keep blood pressure at healthy levels and process proteins. It contains high amino acids especially arginine which is a precursor to nitric oxide which helps keep blood vessels wide enough to keep blood flow normal and thus help control blood pressure. Tiger nuts helps to cure erectile dysfunction, protect the body from cardiovascular disease, may prevent heart attacks, thrombosis, activate blood circulation, gives potassium boost [10]. The oil was found to contain 18\% saturated fatty acid (palmitic acid and stearic acid) and $80 \%$ unsaturated fatty acid (oleic and linoleic acid [11].

Tigernut milk is a healthy and nourishing drink for adults as well as the children. The nutritional profiles and unique functional properties have made tiger nut as unique food [12] like beverage, flour [11, 13], edible oil [14, 15] and a feed source [5]. The anti-nutritional factors especially polyphenols [16] have made it a nutritional source of food. Tigernut can be eaten raw, roasted, dried, baked or be made into a refreshing beverage called tigernut milk [17]. Current research focused on extraction and nutritional value of tiger nut but the information on changing nutrient patterns during its growing cycle is meager. Therefore, the current study was carried out to determine effect of different processing method on proximate and anti-nutritional value of tigernut.

\section{Material and methods}

Matured tigernuts were bought from Michika market in Michika local government Adamawa state.

\subsection{Sample Preparation}

Tigernuts was washed thoroughly in water to remove any adhering soil; different processing methods were used to determine the nutritional quality of the tiger nuts. In each method the tiger nuts were sorted to remove extraneous material.

Tigernuts was divided into three groups, group one was soaked in tap water, group two was roasted, while group three as unprocessed was used. All the samples were made into powder sieved using minor mash size net and stored until use.

\subsection{Equipment used}

Spectrophotometer (Jasco ultra violet spectrophotometer model V-630), Weighing balance (Schimadzu AUN 220D. UniBloc), steam water bath, fume cupboard (AFA 1000 Air flow), Filter Flask, and Oven.

\subsection{Chemical reagents}

Hydrochloric acid, sulfuric acid. $0.3 \%$ Ammonium thiocyanate solution, sodium chloride, ethanol, copper sulphate (hydrate), methyl red, Boric acid, Diethyl ether, Hexane, Sodium carbonate $1.5 \mathrm{NH}_{2} \mathrm{SO}_{4}, 0.1 \mathrm{NKMnO}_{4}$, Anhydrous sodium sulphate.

\subsection{Determination of Antinutritional Factors}

\subsubsection{Determination of Phytate}

Phytate was determined according to the procedure of Price and Butter, [18]. $1 \mathrm{~g}$ of sample was poured into a conical flask $75 \mathrm{ml}$ of $1.5 \mathrm{~N} \mathrm{H}_{2} \mathrm{SO}_{4}$ was added, solution was filtered using filter paper. $5 \mathrm{ml}$ of the filtrate was diluted with $25 \mathrm{ml}$ of distilled water; $15 \mathrm{ml}$ of $0.1 \mathrm{M}$ of $\mathrm{NaCl}$ was added to $10 \mathrm{ml}$ of dilute sample. $15 \mathrm{ml}$ of $0.7 \mathrm{M}$ of $\mathrm{NaCl}$ was taken at 500 $\mathrm{nm}$ spectrophotometrically. 


\subsubsection{Oxalate determination}

To $1 \mathrm{~g}$ of sample $75 \mathrm{ml}$ of $1.5 \mathrm{~N} \mathrm{H}_{2} \mathrm{SO}_{4}$ was added. The solution was filtered, $25 \mathrm{ml}$ of filtered was treated against $0.1 \mathrm{~N}$ $\mathrm{KMnO}_{4}$ solution [19].

\subsubsection{Tannin determination}

Using Trease and Evans, [20] method, $1 \mathrm{ml}$ of methanol extract was treated with $5 \mathrm{ml}$ of Folin-Dennis reagent. The absorbance of the solution of each sample was measured at $760 \mathrm{~nm}$.

\subsubsection{Saponin determination}

$0.5 \mathrm{~g}$ each of the sample was shaken with $5 \mathrm{ml}$ of distilled water in a test tube to determine the absent of frothing which indicate the absent of frothing which indicate the absence of the Saponin.

\subsubsection{Determination of fat}

Fat was determined using AOAC [21], Soxhlet method $5 \mathrm{~g}$ of the sample was weighed into fat extraction. The fat was extracted with petroleum ether $\left(60-80^{\circ} \mathrm{C}\right)$ for $24 \mathrm{hrs}$. The sample was oven dried for an hour. The flask was cooled in desiccators and weighed.

\subsubsection{Determination of moisture content}

Using the AOAC [21] Method $5 \mathrm{~g}$ of the sample was put into petri dish of a known weight and dried in the oven set at $105{ }^{\circ} \mathrm{C}$ for five hours, the dried sample was removed from the oven, cooled in the desiccators and weighed.

\subsubsection{Determination of carbohydrate content}

The carbohydrate content was obtained by calculating the differences between the sum of all the other food nutrient analyzed and subtracted from 100 the total nutrient composition.

\subsubsection{Determination of protein content}

Using Kjeldahl digestion method, $2 \mathrm{~g}$ of the sample was weighed into the "Kjeldahl flask, $10 \mathrm{~g}$ of $\mathrm{Na}_{2} \mathrm{SO}_{4}$ (anhydrous) was added followed by $0.5 \mathrm{~g}$ of copper sulphate (hydrate). The $25 \mathrm{ml}$ of sulphuric acid was added into the flask. The digestion was done inside the fume cupboard.

Distillation: $10 \mathrm{ml}$ of the digested protein was taken into micro- "Kjeldahl distillation apparatus through the funnel followed by $40 \%$ of $\mathrm{NaOH}$ at $100 \mathrm{ml}$, a blue color was formed, as the distillation process continued a dark brown color was formed and ammonia was released, the ammonia could distil until the volume of boric acid was ready for titration.

Titration: The green colored ammonia borate was titrated with $0.01 \mathrm{~N} \mathrm{HCl}$ until the product (pink coloration) was obtained.

$$
\% \text { Protein }=\frac{N \times V \times 14.01 \times 6.25}{\text { Weight of the sample }}
$$

\subsection{Statistical analysis}

Data are reported as Mean \pm SD and were analyzed statistically using one-way ANOVA followed and value of $p<0.05$ were considered significant.

\section{Results}

Table 1 Effect of processing on nutritional value of tigernuts

\begin{tabular}{llllll}
\hline Samples & Moisture (\%) & Ash (\%) & Protein (\%) & Fat (\%) & Carbohydrate (\%) \\
\hline Unprocessed & $9.27 \pm 2.62^{* *}$ & $7.17 \pm 1.44^{*}$ & $17.33 \pm 2.52^{*}$ & $10.17 \pm 2.52$ & $55.7 \pm 5.26$ \\
Soaked & $9.27 \pm 2.26$ & $7.12 \pm 1.44$ & $17.33 \pm 2.52$ & $10.17 \pm 2.02$ & $58.90 \pm 5.32^{*}$ \\
Fried & $6.33 \pm 5.13$ & $5.47 \pm 2.33$ & $13.73 \pm 3.29$ & $8.00 \pm 2.65$ & $64.13 \pm 9,32^{*}$ \\
\hline
\end{tabular}


The proximate analysis indicated no significant difference $(\mathrm{P}>0.05)$ in the three groups of processing. The result indicates no significant effect on the moisture, ash, protein, fat and carbohydrate.

Table 2 Effect of processing on anti-nutritional factors of tigernuts

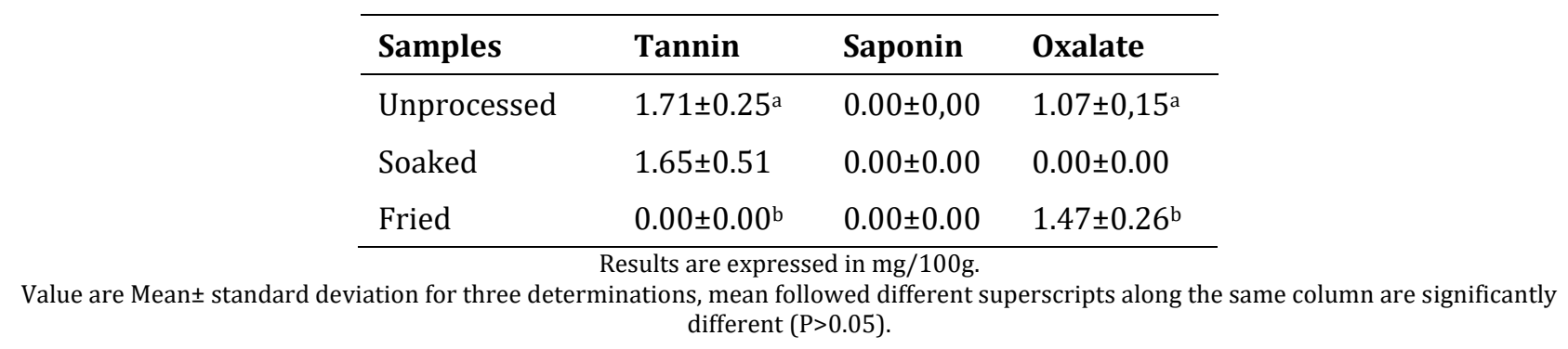

The result in Table ii shows the results of anti-nutrients analyzed. Tannin was significantly reduced $(\mathrm{p}<0.05)$ in fried sample. Oxalate was also significantly reduced by $(\mathrm{p}<0.05)$ in soaked sample.

\section{Discussion}

Three different group of tiger nuts were considered for this research unprocessed, soaking and frying. The two processing methods soaking and frying were carried out on tiger nuts to chick its effect on nutritional and ant nutritional factors as compared with the unprocessed tigernuts. Table 1 shows the proximate composition of tiger nut after processing this indicate little or no significance differences between the processed and the unprocessed nuts group analyzed in terms of moisture, ash, protein, fat and carbohydrate content. But with little difference between the two and the fried nuts. The Moisture content of the soaked and the processed nuts are $(9.27 \pm 2.26$ and 9.27 \pm 2.62$)$ while that of the fried nuts was $(6.33 \pm 5.13)$. However, relating table one and two in determining the efficacy of this methods, table two shows the anti-nutrient value reduced drastically to $\mathrm{P}<0.05$ while the saponin and oxalate absent in soaked method and tannin in the fried method. Thus, the two methods are recommended process for tiger nut food adjunct to adult as well as to the children since it has more of the required nutritional standard when compared with the unprocessed method as shown in the tables above. This agrees with the report of Chevallier, [22] that tiger nuts drink contains more carbohydrate than the Cow's milk, in reference to the fried $(0.00 \pm 0.00)$ and soaked $(1.65 \pm 0.51)$ method the process contain absence and less of tannin than the unprocessed tigernuts with $1.71 \pm 0.25$.

\section{Conclusion}

The research concluded that after the analysis, processing has been found to influence the anti-nutrient level of tiger nut. Thus, soaking and frying method should be adopted in the preparation of tigernut. Considering the nutritive and health benefits of the tigernuts; there is need for increased utilization and awareness of its health benefits as it is rich in vitamin, amino acids, and medicinal factors. Moreover, it is suggested that products from tigernuts should be encouraged so as to solve the problem of protein-calorie malnutrition in Africa. Therefore, high price of imported milk and milk products (for instance) coupled with poor milk production in Nigeria in particular and Africa in general seem to have made consumers more ready to accept milk produced from plant sources. Thus, the need for higher processing methods and biotechnological improvement for high yield should be considered.

\section{Compliance with ethical standards}

\section{Acknowledgments}

The authors would like to thanks department of Biochemistry, Faculty of Science and Technology Yola, and Department of Biochemistry wukari.

\section{Disclosure of conflict of interest}

All authors declare that they have no conflict of interest. 


\section{References}

[1] Odoemelan SA. (2003). Chemical composition and functional properties of conophor nut flour (Tetracarpidium conophorum) flour. International Journal of Food Science \& Technology, 38, 729-734.

[2] Belewu MA and Belewu KY. (2007). Comparative physico-chemical evaluation of tigernut, soybean and coconut milk sources. International Journal of Agriculture and Biology, 9, 785-787.

[3] Turesson H, Marttila S, Gustavsson KE, Hofvander P, Olsson ME, Bülow L, Stymne S and Carlsson AS. (2010). Characterization of oil and starch accumulation in tubers of Cyperus esculentus var. sativus (Cyperaceae): A novel model system to study oil reserves in nonseed tissues. American journal of botany, 97(11), 1884-1893.

[4] Defelice MS. (2002). Yellow nutsedge Cyperus esculentus L.-Snack food of the gods. Weed Technol. 16(4), 901907.

[5] Sánchez-Zapata E, Fernández-López J and Angel Pérez-Alvarez J. (2012). Tiger nut (Cyperus esculentus) commercialization: health aspects, composition, properties, and food applications. Comprehensive Reviews in Food Science and Food Safety, 11(4), 366-377.

[6] David, F. (1986). Human nutritional dietary. Food Encyclopedia. Pp. 35-36.

[7] Mennella JA, Turnbull B, Ziegler PJ and Martinez H. (2005). Infant feeding practices and early flavor experiences in Mexican infants: an intra-cultural study. Journal of the American Dietetic Association, 105(6), 908-915.

[8] Umerie SC and Enebeli JN. (1997). Malt caramel from the nuts of Cyprurus esculentus. Journal of Bioresource Technology, 6, 215-216.

[9] Omode AA, Fatoki OS and Olaogun KA. (1995). Physicochemical properties of some underexploited and nonconventional oilseeds. Journal of agricultural and food chemistry, 43(11), 2850-2853.

[10] Bamgbose AM, Truvbetine D and Dada W. (2003). Utilization of Tiger nut (Cyperus totundus L) meal in the drits for cockerel starters. Bioresource technology, 89(3), 245-248.

[11] Oladele AK and Aina J0. (2007). Chemical composition and functional properties from two varieties of tigernuts (Cyperus esculentus). African Journal of Biotechnology, 6(21), 2473- 2476.

[12] Ekeanyanwu RC and Ononogbu CI. (2010). Nutritive value of Nigerian tigernut (Cyperus esculentus L.). Agricultural Journal, 5(5), 297-302.

[13] Chinma CE, Abu JO and Abubakar YA. (2010). Effect of tigernut (Cyperus esculentus) flour addition on the quality of wheat-based cake. International Journal of Food Science \& Technology, 45(8), 1746-1752.

[14] Muhammad N, Bamishaiye E, Bamishaiye O, Usman L, Salawu MO, Nafiu MO and Oloyede O. (2011). Physicochemical properties and fatty acid composition of Cyperus esculentus (Tiger Nut) Tuber Oil. Bioresearch Bulitein, 5, 51-54.

[15] Lasekan O and Abdulkarim SM (2012). Extraction of oil from tiger nut (Cyperus esculentus L.) with supercritical carbon dioxide (SC-CO2). LWT: Food Science and Technology, 47(2), 287-292.

[16] Okafor JNC, Mordi JI, Ozumba AU, Solomon HM and Olatunji, O. (2003). Preliminary studies on the characterization of contaminants in tigernut (Yellow variety). In Proceedings of 27 th annual Nigerian Institute of Food Science and Technology (NIFST) conference, 210-211.

[17] Adejuyitan JA. (2011). Tigernut Processing: Its Food uses and Health Benefits. American Journal of Food Technology 6(3), 197-201,

[18] Price ML and Butler LG. (1977). Rapid visual estimation and spectrophotometric determination of tannin content of sorghum grain. Journal of Agricultural and food chemistry, 25(6), 1268-1273.

[19] Day RA and Underwood AL. (1986) Quantitative Analysis. 5th Edition, Prentice Hall Publication, Upper Saddle River, 701.

[20] Trease GE and Evans WC. (1978). Pharmacology $11^{\text {th }}$ Ed. Bailliere Tindall Ltd, London, 60-75.

[21] Association of Official Analytical Chemists (AOAC) (1984). Official methods of analysis, Association of Official Chemists, $5^{\text {th }}$ edn. Washington, DC, 10-30.

[22] Chevalier A. (1996). The Encyclopedia of medicinal plants. Dorling Kindersley Press, London. 


\section{How to cite this article}

Umaru HA, Umaru IJ, Aminu A and Kerenhappuch IU. (2018). Influence of different processing methods on proximate and anti- nutritional value of tigernuts (Cyperus esculentus L.). GSC Biological and Pharmaceutical Sciences, 3(3), 29-34. 